\title{
Personal and Private: Using Framing and Network Theory to Examine the Diffusion of Opinion Articles on Facebook
}

Marius Rohde Johannessen

University of South-Eastern Norway

Norway

Marius.Johannessen@usn.no

ABSTRACT: Purpose: Demonstrate the use of framing and network analysis to explore how the two concepts can contribute to understanding diffusion of content in social media.

Design/methodology/approach: Using the most liked and shared opinion articles from Norway's leading newspapers as starting point, the article applies framing analysis to discover which frames are most likely to go viral. Further, social network analysis of the Facebook pages of these newspapers demonstrate the discussion communities and reach of the articles.

Findings: The most popular opinion articles are written in a personal tone and aimed at private and domestic topics. The social network analysis shows that most of these articles generate their own, free-standing discussion communities. The range of engagement with articles posted on Facebook varies a lot, indicating that framing the opinion article correctly is of high importance for generating discussion.

Research Limitations/Implications: The study is limited to one country and two mainstream newspapers. A larger variety in terms of geography and media types is needed for confirmation and future studies. However, the findings confirm that personal framing is important to receive attention in social media. The implications for the wider society can be interpreted both as democratization and as a threat to rational public discourse.

Originality/Value: The study demonstrates a novel approach to study how the framing of opinion articles contribute to diffusion of content in social media. The research approach of framing and network analysis is a process that can be used by newspapers and journalists to track the impact and reach of the stories they publish.

Keywords: Frame Analysis, Network Society, Social Network Analysis, Framing Theory, Social Media, Online Newspapers, Deliberation, Debate, Norway

DOI: $10.6025 / \mathrm{jet} / 2018 / 9 / 2 / 49-64$

Received: 2 February 2018, Revised 27 February 2018, Accepted 8 March 2018

(C) 2018 DLINE. All Rights Reserved

Journal of E-Technology Volume 9 Number 2 May 2018 


\section{Introduction}

Social media and social networks are becoming ever more important for the way we discover and consume news. Several studies (Larsson, 2018, Hermida et al., 2012) show that social media has become a significant source of news for people in many countries. The content our "friends" choose to share is what we are most likely exposed to, and our interactions with this further determines what we see in our feeds (Skogerbø and Moe, 2015). Further, the algorithms choosing what we see seem to favor certain types and styles of content, such as video over images, or images over text (Crawford et al., 2015). In this new reality, media organizations loose parts of the control over content diffusion, while individual influencers and our list of friends become more powerful (Wadbring and Ödmark, 2016). The Arab spring is perhaps the most well-known example of how social media became important for dissemination and had real political and social consequences (Lotan et al., 2011), and more recently the role of social media in Brexit and the Trump election have been discussed.

Issues that are high on the agenda of the news media are often prioritised by politicians (Brewer and McCombs, 1996). Opinion articles, in the form of letters to the editor, are debate-focused genres in the newspaper, written by readers. These articles often address political issues, and can to some extent be seen as insight into the topics that are of interest to the general public, or at least to the more politically interested parts of the general public(Dalton et al., 1998).

Social media and news media have a symbiotic relationship where stories from the news media are shared to, and discussed by, a larger audience in social media (Grzywinska and Borden, 2012). Social network effect has been found to have an impact on dissemination (Guo, 2012). Social media users follow media they either agree or disagree with, and share content to show their support or disagreement on a particular story that they find personally meaningful (Weeks and Holbert, 2013). This use of weak network ties to share news in social media can facilitate the formation of social movements, political campaigns and various protest groups(Svendsen and Svendsen, 2006, Benkler, 2006).

According to framing theory, framing of a story is framed is important for dissemination(McCombs and Ghanem, 2001), as it defines the attributes and themes for how we discuss and engage with different issues(Weaver, 2007). It is this very process of shaping the message which is known as framing: "Framing is the process by which a communication source, such as a news organization, defines and constructs a political issue or public controversy" (Nelson et al., 1997)(p.567).

In a complex world where politics has become both privatised and personal (Graham, 2011) and at the same time also increasingly professionalised and left to experts (Rayner, 2003), combining the concepts of framing and the network society can help us understand the flow of political ideas and discussion, and how they might influence dissemination.

This short introduction leads us to the objectives and research questions of this paper: To analyse the framing of, and networks surrounding, content in successful online newspaper opinion articles, and to examine the potential implications this has for the public sphere2.These objectives translate into the following research questions:

- RQ1: How are the most liked and shared newspaper opinion articles framed?

- RQ2: How are the networks surrounding newspaper opinion articles contributing to spread ideas?

This paper is a response to calls for more research on how and why news are disseminated on social media platforms (Lotan et al., 2011, Weeks and Holbert, 2013), and the call for research on different country contexts (Hermida et al., 2012).

\section{Related Research}

\subsection{Framing Theory}

Framing is concerned with how we construct the stories we tell about the world (Chong and Druckman, 2007). One of the first to introduce the concept was sociologist Erving Goffman (Goffman, 1974), using the concept of frames to show people organize their perceptions of society as a whole and of specific aspects of society. Framing relates to attitudes, and can be measured as the sum of positive and negative associations with a given issue (Chong and Druckman, 2007). These attitudes influence how we choose to talk about the issue. For example, if a company wants to build office buildings in your city, which will generate jobs and income but have a negative effect on the local environment, your attitude towards the project can be determined by the value you put on the economy vs environmental and "green" issues. This becomes a frame that determines how you talk about the issue. A newspaper reporter in favour of the environment will write more about the negative environmental impacts of the 50 Journal of E-Technology Volume 9 Number 2 May 2018 
build, while another reporter focused on the economy will write about how the project is great for the local economy. Framing is a way of limiting the issue we are talking about, as it decides what we choose to put into a concept and what we choose to leave out (Callon, 1998).

Several studies have examined the effects of framing on the public's perceptions of an issue. These studies show that framing has a clear impact on our perceptions, especially when we do not have a clear preference on the issue, or if the framing supports our own views (Hardisty et al., 2010). In Norway, the protest group ATTAC was successful in gaining media attention and managed to become an important voice in the late 90's and early 2000's debate on globalisation. This success was due to the successful framing of their message (Sandberg, 2003).

Other scholars have studied how and why framing works. A study found that framing alters the weight assigned to our beliefs (Lecheler and de Vreese, 2012). Read the same message about global warming long enough, and we start being concerned about it. The introduction of new ideas and new information, showing us content we had no previous awareness of, i.e. reading about global warming for the first time, is another way that framing affects us. A literature review found that successful framing had effects related to the dissemination of information and persuasion of readers(Tewksbury and Scheufele, 2009).

Another issue is how we should regard frames. Frames can be seen both a tool for sense making (Callon, 1998, Weick et al., 2005) and as a means of convincing others about how to see a specific issue. The latter view is more prevalent in fields such as marketing/PR (for selling a product or story) and social movement theory (for convincing people to join the movement) (McAdam et al., 1996).

Interactions without frames are hard to make sense of (Bateson, 1972). When people discuss an issue, real interaction is difficult if the frames we apply have little overlap. When financial matters are most important, you disregard the environmental costs. Those who are concerned only with the environmental impact see financial matters as meaningless. In these situations, it becomes difficult to truly deliberate and reach agreement on an issue. Sensemaking occurs when frames have clear boundaries where "explanations hold and outside of which they do not hold"(Weick, 1995) (p. 176). As people agree and strengthen a certain frame, they become committed and seek to justify their view through further strengthening the frame. If we believe in Weick's view that situations, organisations and contexts are talked into existence, we see how applying a frame and convincing others that this framing holds true can be a powerful weapon.. The section on network theory takes this line of reasoning further, by examining how networks can help spread the message and convince more people of the frame's validity.

\subsection{Conducting Frame Analysis}

We can analyse the framing process using a number of different approaches. This section provides an overview of the most common approaches to frame analysis. Table 1 summarises the different approaches identified in literature.

\begin{tabular}{|l|l|l|}
\hline Approach & Purpose & Insights gained \\
\hline $\begin{array}{l}\text { Qualitative content analysis Coding } \\
\text { of qualitative data: Keywords, key } \\
\text { phrases, judgment statements }\end{array}$ & $\begin{array}{l}\text { Identify themes and topics Interpret } \\
\text { meanings of texts to identify frames } \\
\text { for the different themes and topics }\end{array}$ & $\begin{array}{l}\text { Rich description of the frames used to talk } \\
\text { about a specific issue. }\end{array}$ \\
\hline $\begin{array}{l}\text { Quantitative content analysis } \\
\text { Follows pre-defined coding scheme } \\
\text { based on hypotheses }\end{array}$ & $\begin{array}{l}\text { Using frames to examine issues of } \\
\text { statistical significance. Impact over } \\
\text { time. }\end{array}$ & $\begin{array}{l}\text { Time series data, tendencies/ } \\
\text { consequences of frames }\end{array}$ \\
\hline $\begin{array}{l}\text { Mixed methods Approach varies } \\
\text { according to research question }\end{array}$ & $\begin{array}{l}\text { In-depth analysis and identification } \\
\text { of frames, and of the impact of frames. }\end{array}$ & $\begin{array}{l}\text { Impacts and tendencies mixed with a deep } \\
\text { understanding of context and the } \\
\text { individual frames }\end{array}$ \\
\hline
\end{tabular}

Table 1. Summary of research methods, frame analysis

Reese points out that empirical analysis of frames can be both quantitative/positivist and qualitative/interpretive (Reese, 2010). Bishop (2013) applied frame analysis to media coverage of play. He collected texts from US newspapers and transcripts from 
national TV news and performed a qualitative content analysis because "a quantitative content analysis would not have enabled the author to unpack the layers of meaning found in the texts" (p. 513).

Kang (2013), in his study of autism, follows a similar approach of identifying themes and following a coding scheme for the identification of frames, but applies quantitative content analysis and statistical methods to identify frames and to examine how these frames have changed over time.

Silberberg (2008) and Yarnell (1985) argue for a mixed-methods approach, where the research methods applied varies according to the research question.

\subsection{Online Newspapers' Role in Shaping Public Opinion}

In Norway, both the Internet and newspapers have a strong position. According to the Bureau of Statistics $1,75 \%$ of Norwegians read a printed newspaper at least once a week, and $85 \%$ use the Internet every day. As many as $61 \%$ of Internet users visit at least one online newspaper. While print readerships have dropped significantly in recent years, online readerships and subscriptions are on the rise, and newspapers remain one of the most important sources of information for Norwegians. However, social media is on the rise, and according to the TNS media survey ${ }^{2}, 56 \%$ of Norwegians use social media to meet their needs for information, and $71 \%$ respond that the newspaper (on- or offline) meets their needs for information. As there is some overlap between the media channels, these numbers support the findings of Grzywinska \& Borden, which claims that social media and traditional media are in a symbiotic relationship where traditional media extends its user base through sharing in social media (Grzywinska and Borden, 2012).

\subsection{Network Society and Network Analysis}

The importance of this symbiotic relationship becomes even more visible when we take into account the notion of the network society. Western society is increasingly organized through networks, and networks influence culture, business and politics alike (Castells, 2000). A network consists of nodes (the individual parts of the network) and the connections between these nodes. Nodes can be individuals, organizations, societal institutions, business and government (Barney, 2004). Studies in marketing have shown powerful network effects from the sharing of content, especially when the one sharing is seen as an influencer in the network (Katona et al., 2011). An increased awareness of the fact that content is framed can aid us in being more critical citizens, as being part of a social network where you are exposed to alternative arguments and different sources of information leads to a more informed public, which is less likely to be persuaded by how others frame an issue (Chong and Druckman, 2007).

Social network analysis can contribute towards this form of analysis (Smith et al., 2009). Social network analysis allows us to examine how information flows through a complex network, and allows us to visualise and analyse networks through examining the connections and attributes of connections between nodes. The strength and number of connections between actors in a network implies both community, which is important for strengthening frames, and that the message and frame is spread to a wide audience (Smith et al., 2009).

The basic use of network analysis is to identify patterns of interaction among the participants in a network. Typical variables measured are:

- Degree: The number of participants a given participant interacts with, can be split into receiving (in-degree) and sending (outdegree) messages. High degree levels indicate strong networks and community.

- Centrality: How important a participant is to the network. Measured as closeness (the number of nodes between two participants), betweenness (how each participant helps connect other participants), and eigenvector (how well a participant is connected to other active participants).

- Clustering: The degree to which a set of participants form a group within the network (Mazur et al., 2010).

- Density: The proportion of actual vs. potential connections within the network (Otte and Rousseau, 2002).

\footnotetext{
${ }^{1}$ http://www.ssb.no/medie

${ }^{2} \mathrm{http}: / / w w w . t n s-g a l l u p . n o / m e d i e r / a v i s$
}

$52 \quad$ Journal of E-Technology Volume 9 Number 2 May 2018




\section{Research Approach}

The research presented here has been conducted following a qualitative research approach with an interpretivist epistemology. This approach is appropriate because framing concerns the creation of meanings, and meanings are in their very nature interpretive (Reese, 2010). Data was collected over two rounds. The first round focused on the most shared and most liked opinion articles from two of Norway's leading online newspapers. This provided me with 40 articles for analysis, covering different topics and published throughout 2014. The data was imported to the Nvivo software package for qualitative research, and analysed using a frame analysis approach, as outlined by Reese (2010) and Bishop (2013). Because the number of articles is limited and the selection is so heterogeneous in terms of the topics addressed, frames are identified from a macro-perspective. For example, the frame "deliberation" could easily be broken down into smaller frames based on the actual argument. Given the limited number of articles within the frame, this would however not allow me to identify patterns of interest in the data.

Reese (2010) points out that the frame analyses should always start with answering a set of questions: Where does the frame reside? In text, culture or in the mind of the receiver? How do we know that a frame actually exists, or is it simply a construction by the researcher or the reader? What is the unit of analysis? What is the relationship between frames and dissemination, and how do we separate topics and themes from the frames used to present them? For this paper, the answers are as follows: The frame resides in text, in the arguments structuring the opinion article. Being an interpretive study, the frame exists as a construction based on the researcher's interpretations of text. We can code the story about the drunk driving of famous cross-country skier in several ways, such as justice, celebrity blunders or drunk driving. Categories were deliberately coded into relatively broad categoriesto limit the total number.

The unit of analysis is the individual article. Topics and themes are separated from frames through the coding process, as these are the first items to be identified for each article. The actual coding process is influenced by Bishop (2013): The individual article is coded by first identifying the theme of the article, then searching for key words and phrases, as well as judgment claims.

The coding process followed a grounded, iterative approach. Specific sections of the texts were coded as different themes and frames, to create a coding scheme. In the second round of coding, the texts were coded with the identified themes and frames. I performed the first two rounds of coding, and verified my findings through having a colleague examine and comment on the data set and findings.

In addition to the frame analysis, Descriptive statistical analyses using SPSS and Nvivo were also performed. Word-frequency analysis, and cross coding of nodes to identify issues such as how many women and men used specific frames for their articles, and how many of these were unknown writers (people who are not hired as comment writers, run a popular blog or are frequent writers in the letters to the editor section). This allows for a more mixed-method approach, as argued for by (Yarnell, 1985).

The frame analysis pointed towards the second research question regarding networks and their role in spreading information. This led to a second round of data collection and analysis. All the posts from the Facebook pages Aftenposten meninger and Dagbladet meninger were collected using the Netvizz ${ }^{1}$ application for Facebook. Netvizz allows you to download content from Facebook pages (all posts and interactions). This provided a data set of about 400 opinion articles posted on Facebook, and 40.000 interactions (likes, comments) to these articles. The output is given as csv (for statistical analysis) and gdf (for network analysis) file formats. Social network analysis was performed using the open source SNA tool Gephi ${ }^{2}$. In addition to these tools, SPSS was used for descriptive statistics, and the tool Issuecrawler ${ }^{3}$ was applied to examine if there were any notable networks among those who like the two newspapers on Facebook, and to examine any interlinking between different media outlets on the most liked and shared stories.

\section{Findings}

The two newspapers selected for analysis are two of the largest online newspapers in Norway, based on number of readers.

\footnotetext{
${ }^{3}$ https://apps.facebook.com/netvizz/

${ }^{4}$ http://gephi.org/

${ }^{5} \mathrm{http}: / / \mathrm{www}$. issuecrawler.net
} 
Dagbladet.no had 1.906.000 readers in 2014, and Aftenposten.no had 1.162.000. Looking at the list of most visited web sites in Norway, published by the Norwegian Media Businesses' Association ${ }^{1}$ (NMBA), we find newspapers at five of the top ten most read web sites. The other sites are weather forecasting service yr.no, classifieds site finn.no and the national broadcaster NRK, as well as "other services", where we find social media and other web sites. Both Dagbladet.no and aftenposten.no ranks in the top ten most read web sites in Norway. This is a clear indicator of the importance of newspapers in Norway. Table 2 shows a summary of statistics for the two newspapers, including their Facebook and Twitter readership (both newspapers have "share on Facebook/Twitter buttons attached to each story). On Facebook, both newspapers have a separate page for opinions and letters to the editor. This page is also included.

\begin{tabular}{|l|l|l|l|l|l|}
\hline Title & Web & Twitter & Tw., opinion & Facebook & FB, opinion \\
\hline Aftenposten & 1.162 .000 & 65600 & 13200 & 194248 & 21680 \\
\hline Dagbladet & 1.906 .000 & 5677 & 4035 & 95010 & 64781 \\
\hline
\end{tabular}

Table 2. Statistics for the two newspapers in the study

Facebook is by far the most popular channel for sharing. 42.000 people on Facebook, and only 452 times on Twitter shared the article that was on top of the most shared list. We see this trend across all the examined articles, where 100+ people share in Twitter, while Facebook sharing is in the tens of thousands. The articles were published throughout the year, at different times of day.

Table 3 shows descriptive statistics for Aftenposten's opinion page on Facebook. Engagement refers to every time a user likes or comments on something that is posted on the site. While total engagement is quite high, there are few repeat users. When removing those who have less than five interactions, about 70 percent of the users disappear from the list.

\begin{tabular}{|l|l|l|l|l|l|l|l|}
\hline & $\mathbf{N}$ & Minimum & Maximum & \multicolumn{2}{l|}{ Mean } & Std. Deviation & Variance \\
\cline { 2 - 8 } & Statistic & Statistic & Statistic & Statistic & Std. Error & Statistic & Statistic \\
\hline Total Engagement & 17968 & 1,00 & 222 & 2,6194 &, 04780 & 6,40713 & 41,051 \\
\hline Comments on post & 17968 &, 00 & 125 &, 2014 &, 01241 & 1,66339 & 2,767 \\
\hline Comment replies & 17968 &, 00 & 18 &, 0059 &, 00145 &, 19388 &, 038 \\
\hline likes & 17968 &, 00 & 194 & 2,4121 &, 04284 & 5,74302 & 32,982 \\
\hline \multicolumn{1}{|c|}{ ValidN } & 17968 & & & & & & \\
\hline
\end{tabular}

Table 3. Descriptive statistics Aftenposten's Facebook opinion page

Table 4 shows the descriptive statistics for Dagbladet's opinion page on Facebook. The same findings apply here, but Dagbladet's users are somewhat more likely to engage other users by replying to their comments.

\subsection{Word Frequency and Frame Metadata - Closeness, Personal Issues and New Voices}

The frames dataset was input to Nvivo, and in addition to the coding of the actual frames, a word frequency analysis and the authors' background were recorded. The word frequency shows that the issues close to home get more attention. Norway/ Norwegian is mentioned 136 times, while Europe/European is only mentioned 15 times, and only in four of the 40 articles. Frequently used nouns give us a hint of the themes that are important. These include "children", "school", "work", and

${ }^{6} \mathrm{http}: / / w w w . m e d i e b e d r i f t e n e . n o / T a l l — F a k t a 1 / L e s e r t a l l / l e s e r t a l l-a v i s-h o s t-2014 /$ 


\begin{tabular}{|l|l|l|l|l|l|l|l|}
\hline & N & Minimum & Maximum & Mean & Std. Deviation & Variance \\
\cline { 2 - 8 } & Statistic & Statistic & Statistic & Statistic & Std. Error & Statistic & Statistic \\
\hline Total Engagement & 20219 & 0 & 84 &, 35 &, 013 & 1,808 & 3,270 \\
\hline Comments on post & 20219 & 0 & 53 &, 09 &, 006 &, 874 &, 763 \\
\hline Comment replies & 20219 & 0 & 304 & 2,28 &, 037 & 5,277 & 27,849 \\
\hline likes & 20219 & 1 & 304 & 2,72 &, 044 & 6,278 & 39,409 \\
\hline Valid N (listwise) & 20219 & & & & & & \\
\hline
\end{tabular}

Table 4. Descriptive statistics Dagbladet's Facebook opinion page

"women", reflecting the most common themes found in the articles. Unknown writers (writers who are not regular columnists, well-known bloggers or frequent contributors to the opinion section of newspapers) write more than half of the articles, and around half of the writers are women. Only six writers have an academic background. This indicates that social media sharing does help new to include new voices in the public sphere. Personal issues are the most popular themes: Health, gender/body, parenting and education make up $75 \%$ of the articles. This supports Graham's (2011) view that the personal sphere has become an important part of public debate.

\subsection{Frames}

Six frames were identified. The first frame, metaphor, was found in one article that used a fairy tale figure to discuss current social issues. "Askeladden" is a stereotype of the idealized Norwegian, the underdog who succeeds by being creative and thinking outside the box, and who thinks more about others than about himself. The article uses the metaphor to show everything that is wrong with Norwegian society today:

"Askeladden helped those in need. When others needed him, he forgot about his own issues and needs. Personal kindness translated to politicsis solidarity... However, now the welfare state is threatened. Social inequality is on the rise. The number of poor children increases. The wealthy do not have to pay taxes"

The second frame is satire/irony. Three articles use this to frame their message. They do this to ridicule the position they are arguing against, in order to convince the reader that there is only one way of interpreting said issue. A columnist comments on the teacher's strike in the autumn of 2014, ridiculing the arguments made by those who oppose the strike:

"After all, the strike affects an innocent third party. I am not thinking about the students. No one cares about students. I am of course thinking about myself. And people like myself."

Another article discusses gender stereotypes used in advertising, and uses male stereotypes to argue against this form of advertising:

"How many of us see these images and think 'yes, we can relate to this. Party and drinking trips to European brothels, where we party all night with heavy-chested women who has no personality?"

The third frame identified is Outrage, The frame usesarguments related to justice, fairness and equal treatment to frame the message. Two articles use this frame, one discussing terrorism and the treatment of Anders Behring Breivik, the other discussing the drunk driving of a famous cross-country skier:

"You can't call yourself a victim of the media in this case. No one in VG [Norwegian newspaper] gave you a bottle of vodka and Audi the last time I checked. You are a huge role model for young kids, who now might think that drinking and driving is ok. Therefore we should all be happy that this episode is so massively criticized in the media." 
Another frame, used in four articles, is pressure. This frame focus on the psychological pressure that faces us in modern society, and argues that we need to find ways of lessening pressure. Peer pressure, parenting and the pressure to be the best at everything are topics within this frame, which has a clear "them and us" perspective. A liberal Muslim woman is tired of the peer pressure she claims comes from conservative Muslims in her surroundings:

«I am sick and tired of Muslims who think they are better than the rest of us. Why do they insist on being so different? Do they believe God loves them more than us? The Niqab does not just represent oppression, but also arrogance."

Pressure related to parenting and testing in schools are other issues. The following quote is an example from an article incorporating both of these topics:

"At supper, 6.30 PM a Tuesday in May, we receive a call from a concerned teacher. Our six year old boy is having trouble separating the letters ' $\mathrm{b}$ ' and ' $\mathrm{d}$ '.... and there is a test tomorrow...It is thought provoking that a teacher has to call parents late at night about this. Who is it really that is being tested tomorrow? The pupil or the teacher?"

Deliberation is the frame of the classical debate article. This frame presents arguments backed up by reasoning and references to literature. The objective is to convince the reader through presenting facts and rational arguments. It is not surprising that the six academic authors and the established commentators are the most frequent users of this frame. The topics found in this frame relates to politics and society, discussing the dangers of drugs, financial policies, international politics and women's rights. Ten of the examined articles falls within this frame. While the topics vary, their content is such that they are relevant to large numbers of people. For example, the article discussing NATO does so in a context of Russian expansion in the Ukraine, and the dangers a strong Russia poses for Norway:

"The Russian insurances comes after Russia several times the past few months have entered Swedish airspace with their fighters, and after several military provocations of all their European neighbours, including Norway"

The last frame is perhaps the most interesting one. More than half of the articles are framed as a personal account of events, where the author describes his or her experiences in relation to a theme, and discusses the theme based on these experiences. The articles framed as personal accounts are the most shared articles by far, showing that content we as readers can relate directly to, which addresses issues we are concerned with, is perhaps the best way of gaining attention and reaching a broad audience. The topics in this category varies greatly, ranging from terrorism to education and parenting. What the articles do have in common is how they address something they perceive as a societal issue through personal experience, and how they relate these personal experiences to a broader context. An anonymous mother discusses the failure of kindergartens to avoid bullying through an account of her three-year-old daughter's daily life:

"Now I suddenly understand the more than 50 necklaces she has brought home from kindergarten the past few months. Each piece is made out of loneliness, exclusion and small children's hands, alone at a table"

In another example, a woman discusses the pressures of modern work life through the story of her own illness:

"I'm burnt out. Exhausted and depressed. On sick leave because I could not handle it all anymore. They call it hitting the wall. I would rather compare it to walking off a cliff. I did not see a wall, I did not feel a crash, and it never stopped. Suddenly I just lost my footing and fell.

This frame most clearly reflects the general findings in section 4.1. The issues that seem closest are the most engaging ones. The writers are new voices in the public sphere, and while their message is personal, the readers seem to find something universal in the stories they read.

\subsection{Social Network Analysis}

\subsubsection{Inter-linking between Websites}

The first analysis performed was an examination of in-links from other web sites to the list of most read and shared opinion articles. The issue crawler tool was used for this analysis. The list of URL's were sent to Issue crawler, which examined the network of URL's linking to these stories.

$56 \quad$ Journal of E-Technology Volume 9 Number 2 May 2018


The total network is quite large, with 10.056 nodes. However, when we examine domains instead of individual URL's, the number of actors is reduced to 368. Twitter and Facebook are the two domains with the most links to the most read and shared opinion stories. The third is the Norwegian press association's web site. The other sites in the top 10 are all domains that in some way or another belong to either Aftenposten or Dagbladet, meaning that a majority of links comes from internal sources. This means that outside of the social media realm, you are more likely to follow a link to these stories if you already are within one of their sites. Some Norwegian and international media also have links to Aftenposten and Dagbladet (NY Times, BBC, the Guardian, Reuters and others), but even the total number of links from these domains is less than the number of links from even one social medium. This emphasises the importance of social media for the traditional media industry, and in cases relevant to the political realm. However, the number of links from other sites is still quite high, so in that sense this finding supports earlier research arguing for multi-channel approaches (Ebbers et al., 2008).

\subsubsection{Inter-linking between Blogs}

Political blogs have in earlier studies been found to be important actors in policy-making(Park and Jankowski, 2008, Meraz, 2009, Macintosh et al., 2005). Thus, a network analysis of Norwegian political blogs that linked to any of the most read and shared opinion stories was performed. The reason for this analysis was to examine if a story lives on in the blogosphere after the newspaper has published it. This analysis revealed that very few political blogs actually link to the most read and shared opinion articles. Six blogs were identified and verified to be political in nature. These have a certain degree of linking between one another. While this should not be seen as a rejection of blogs as a platform for political discussions, in this particular case blogs are not very relevant as parts of the network surrounding the most read and shared opinion stories.

\subsubsection{Social Network Analysis of Facebook Opinion Pages}

The social network analyses of the Facebook pages (all posts from 2014, not just the most shared ones) shows some interesting findings. Gephi allows us to focus on different aspects of a network. In this case, three areas were seen as interesting: The communities within the page, as calculated by the modularity score (Blondel et al., 2008)shows interactions between the nodes in the network, and examines if there are communities where members have more than one interaction with each other. The presence of communities shows that a network is more than a random collection of nodes that only interact once.

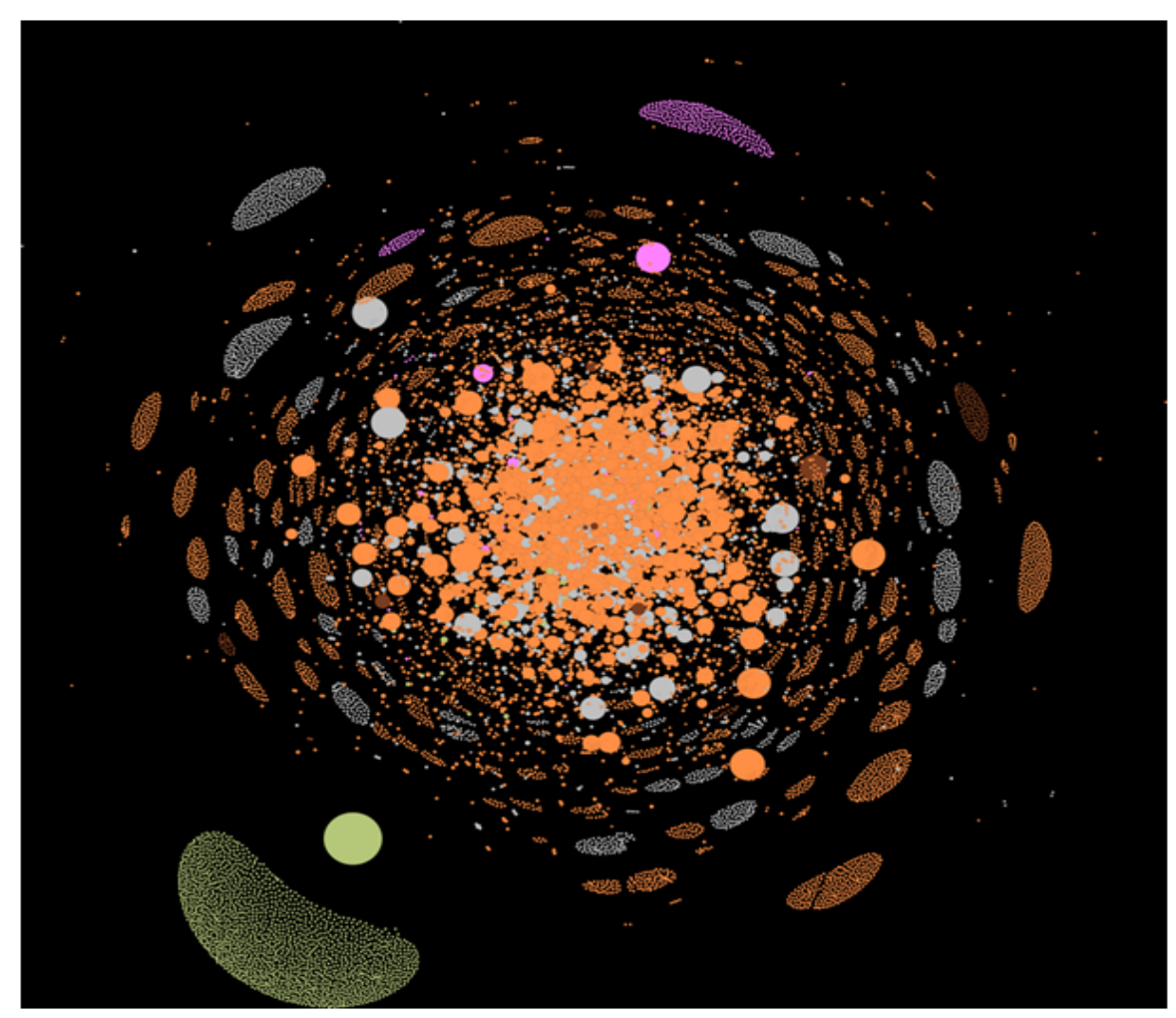

Figure 1. Aftenposten communities 
Second, focusing on outliers shows which topics that receive the most interactions, and if there are distinct communities centred around certain posts. Denser networks with more interactions are typically more easy to model as communities, while outliers appear in networks where a lot of nodes gather around one or several strong nodes, where the strong node acts as a bridge between actors in the network.

Finally, the pagelink network shows the network of pages that potentially have access to posts published on Dagbladet and Aftenposten meninger. This network is set up with two degrees of separation. With two degrees of separation, you can uncover which nodes in a network has access to content shared by a page they follow. So if for example the Labour party follows Aftenposten and share a post from them to their own followers, the followers of the Labour party are potentially part of the network stemming from Aftenposten.

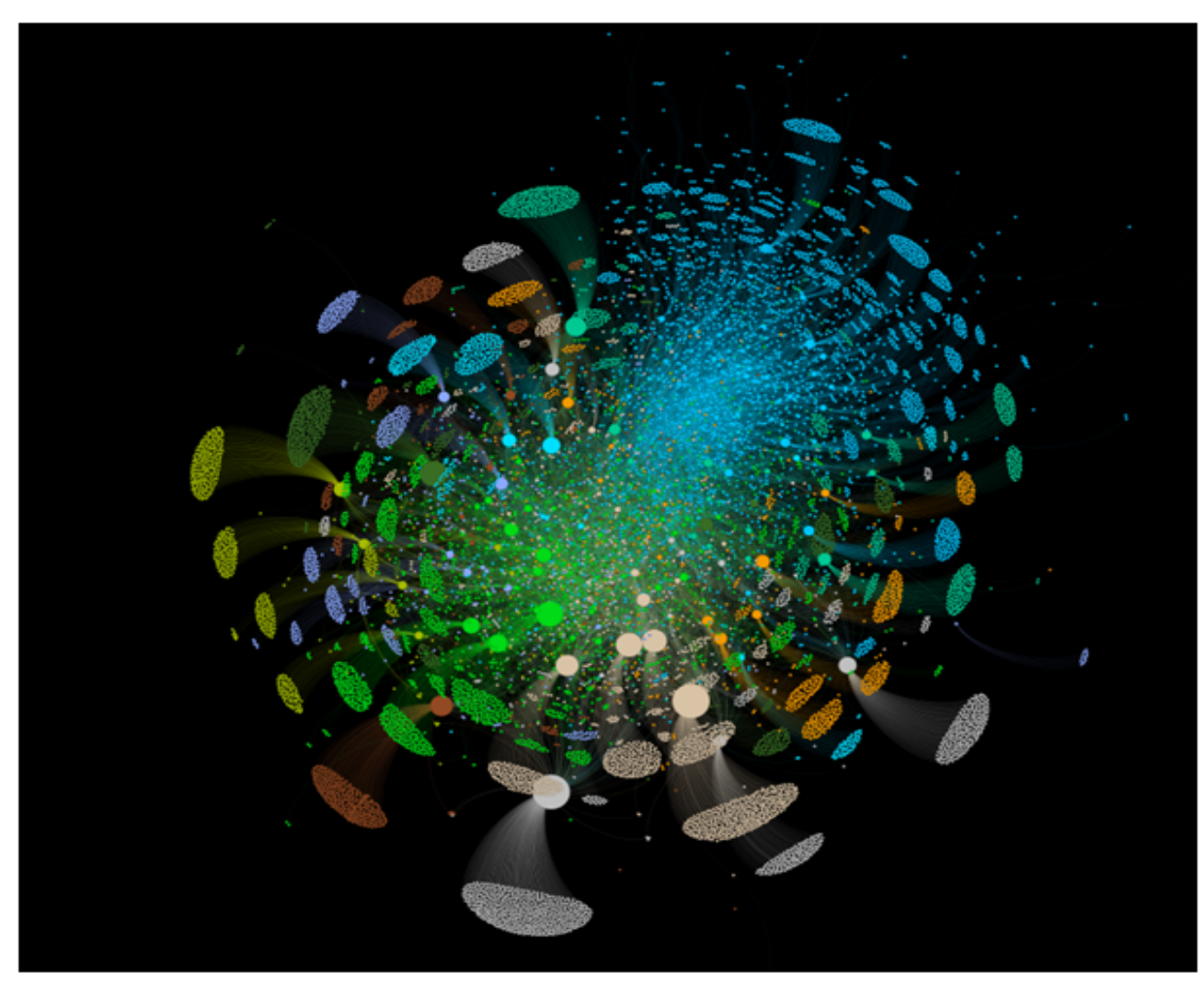

Figure 2. Dagbladet communities

Figures 1 and 2 show communities in the two Facebook pages. Both visualisations were made using the Yifan Hu algorithm. In order to show the different communities more clearly, nodes with a weight less than 10 were removed. We see that both pages have core communities consisting of people who frequently interact with several posts. In Dagbladet, it seems there are two core communities, while Aftenposten has one. The network cores are small compared to the total number of interactions. When you remove those who have only made one interaction, you are left with 33 percent of nodes in Aftenposten, and 37 percent in Dagbladet. Removing those with three or fewer interactions leaves us with $\sim 18$ percent in both cases.

Looking at comments only, Aftenposten has 51 people who have left ten or more comments, while Dagbladet has 131. For total engagements (likes and comments) the numbers are 811 (Aftenposten) and 938 (Dagbladet), showing that people are far more likely to like a post than to comment. The graphs in figures 1 and 2 clearly shows how several small communities form in the fringes of the network.

Figures 3 and 4 focus on the outliers, those who participate in the fringes of the community. Especially for Aftenposten, we can see that three of the most popular posts generate a lot of one-time interactions and short discussions around that particular

\begin{tabular}{llllll}
\hline 58 & Journal of E-Technology Volume & 9 & Number 2 & May 2018 \\
\hline
\end{tabular}




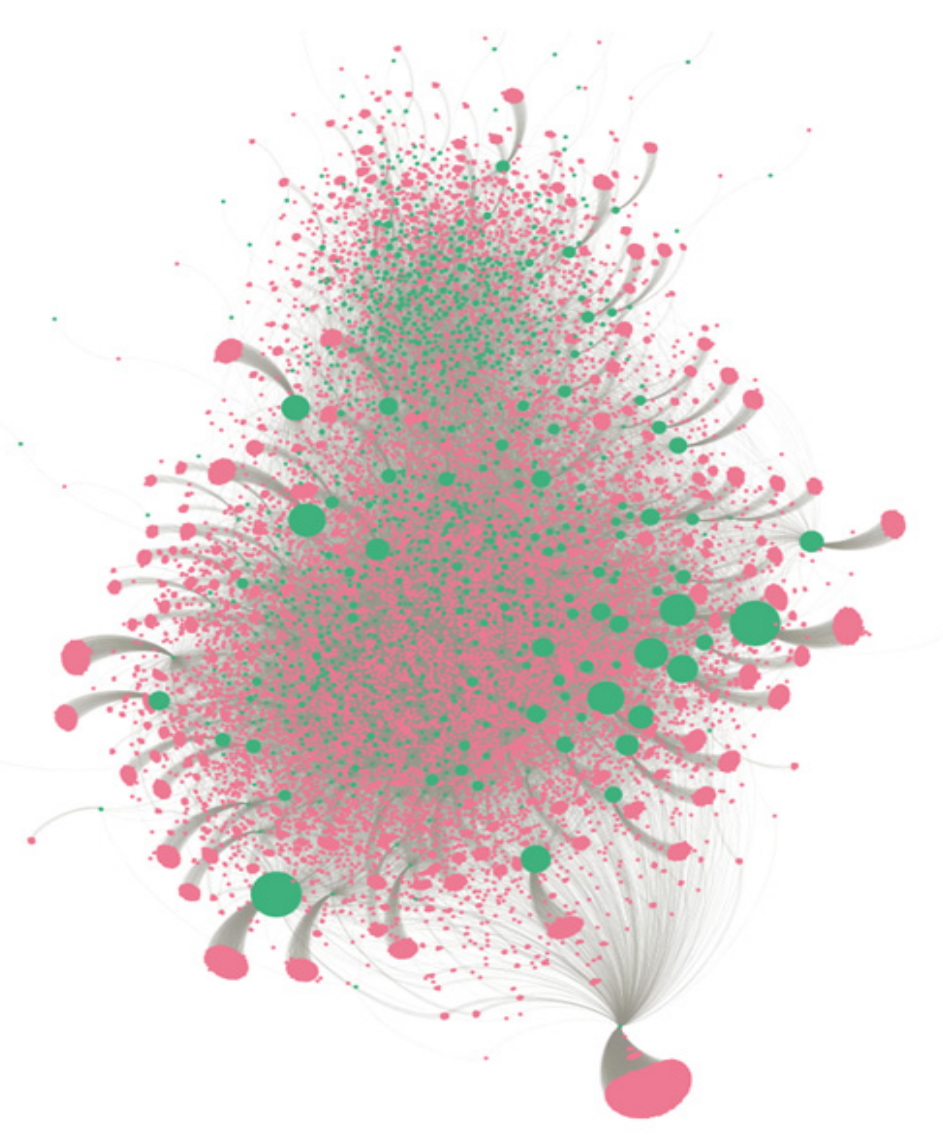

Figure 3. Outliers in Dagbladet

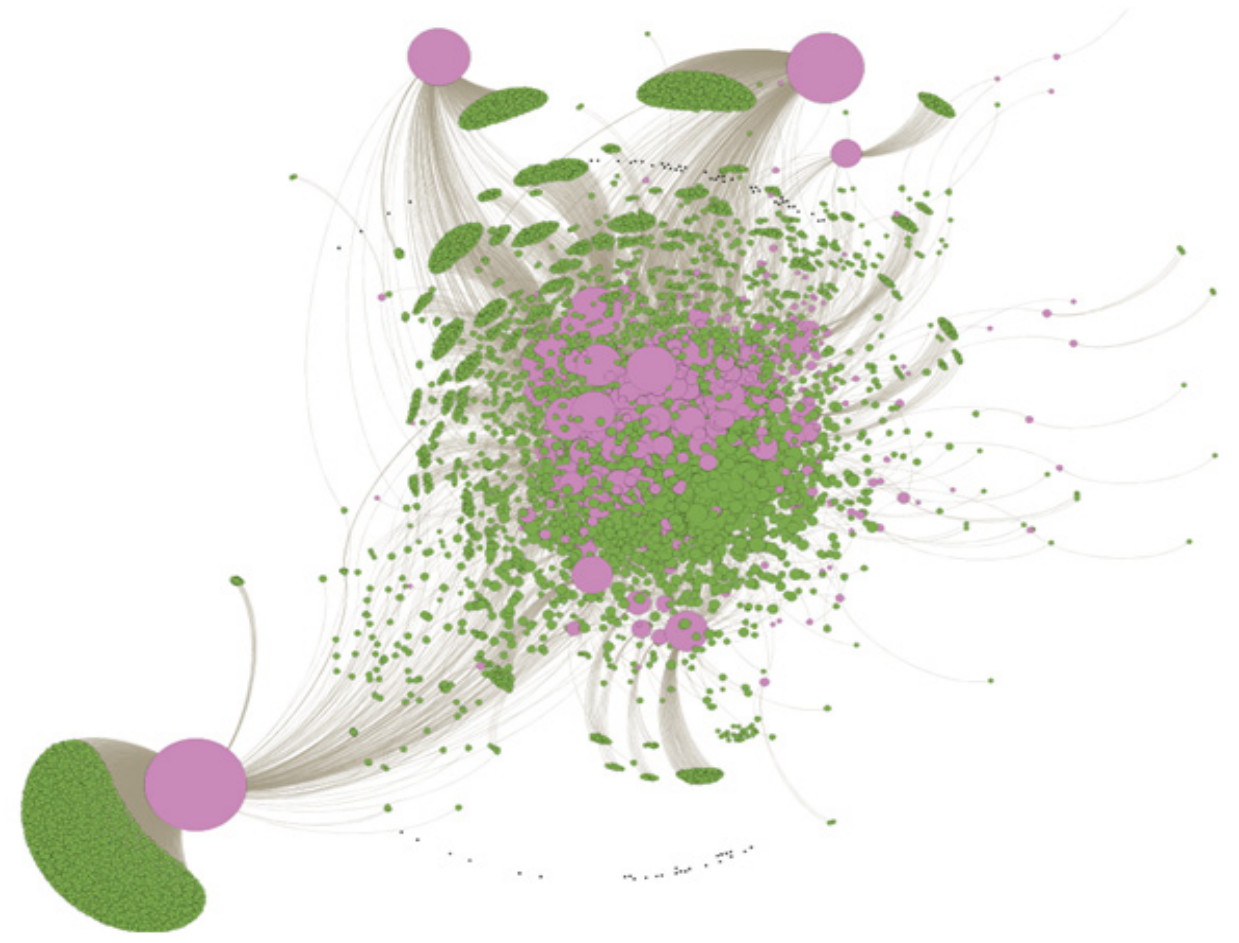

Figure 4. Outliers in Aftenposten 
topic. Dagbladet also has a lot of participants who only contribute to one or two posts, but participants here are scattered across more posts, forming several small one-post communities. Not surprisingly, the most popular posts correlate with the list of most shared and most read opinion articles that is the basis for the frame analysis.

Table 5 presents the network measures for the two pages. The average degree is the average number of connections for each node in the network. Path length is the average length from point A to point B in the network. High scores indicate a dense network. With a path length of 1 , none of the networks can be seen as highly connected. Aftenposten has 39 identified communities, with 250-1750 nodes in each. Most of them are on the lower end. Dagbladet has 121 communities. Most of them have between 10 and 20 nodes, while 24 has 250 nodes or more. The maximum number is 3200 . For both pages, network density is 0 , which again indicates very little interaction between participants, except for in single posts. Another measure of community can be the edge weight of connections. Higher numbers means that the same two nodes have more interactions. 1025/2296 edges have 2 or more interactions, meaning that a person has places two comments, two likes or one of each on the same post. Only 10 edges in Aftenposten have more than five interactions, and 74 in Dagbladet. Hence, ongoing conversations are rare in both sites, but a fair number of people spend at least some time with the post.

\begin{tabular}{|l|l|l|}
\hline & Aftenposten & Dagbladet \\
\hline Avg degree & 4,1 & 4,9 \\
\hline \# edges with 2+ weight & 1025 & 2296 \\
\hline \# edges with 5+ weight & 10 & 74 \\
\hline Centrality (path length) & 1 & 1 \\
\hline Clustering (\# communities) & 39 & 121 \\
\hline Network density & 0 & 0 \\
\hline
\end{tabular}

Table 5. Network measures

In conclusion, the Facebook pages of Dagbladet and Aftenposten are not strong communities. Dagbladet has more recurring connections that Aftenposten, which could indicate that they have a few more participants who actively engage with content posted on the page. However, both pages' strength is in their reach rather than in their function as arenas for ongoing debate. Even so, 39.000 people have at least one engagement with content posted on the site, so we should not underestimate the power of these pages when it comes to dissemination of a message.

The final analysis is of the page like networks of Dagbladet and Aftenposten. The visualizations in figures 5 and 6 show two degrees of separation for the pages that like Aftenposten and Dagbladet, meaning that those who follow page A will see interactions page A has with Dagbladet or Aftenposten. Hence, the pagelike network can tell us something about the potential audience of the pages.

\section{Discussion and Implications}

This paper has examined popular opinion articles from two online newspapers, using frame analysis to identify how writers frame a popular article. The analysis revealed six frames. One of these, the personal account, accounts for more than half of the examined articles. Except for an article by Steven Hawking the articles using this frame are at the very top of the list of shared content.

It seems texts playing to our emotions and feelings has become the preferred mode of communication for a large part of the population, as demonstrated by for example Crawford et al. (2015) and confirmed here. This can be interpreted in several ways: One way is to see this as an answer to the professionalization of politics, and a form of protest against the fact that decisions are becoming ever more rationalized and based on expert opinion, research and reports. In this sense, we are perhaps witness to a grassroots rebellion against the current state of affairs. On the other hand, a public that is ruled by emotions can also be seen 


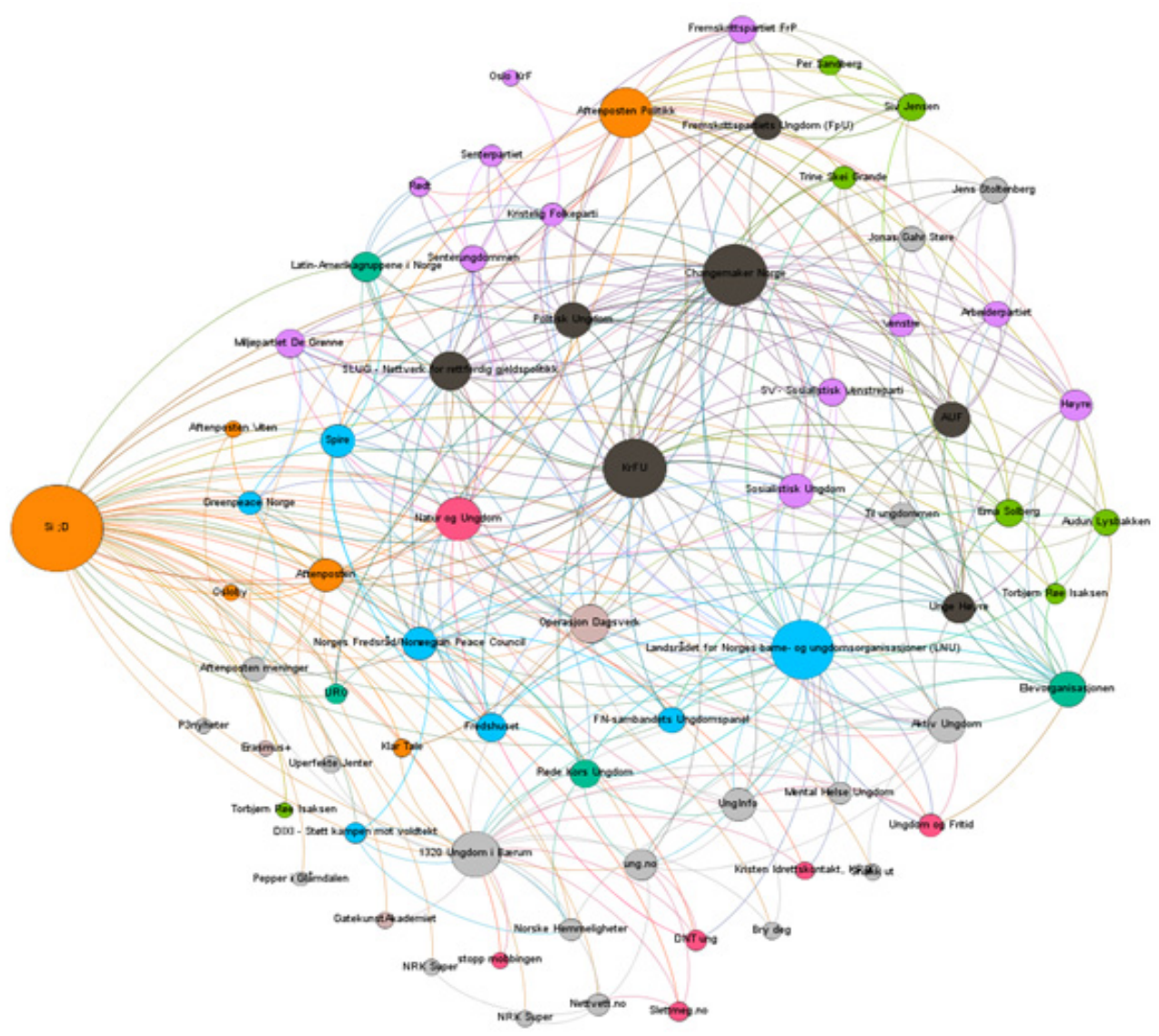

Figure 5. Aftenposten page like network

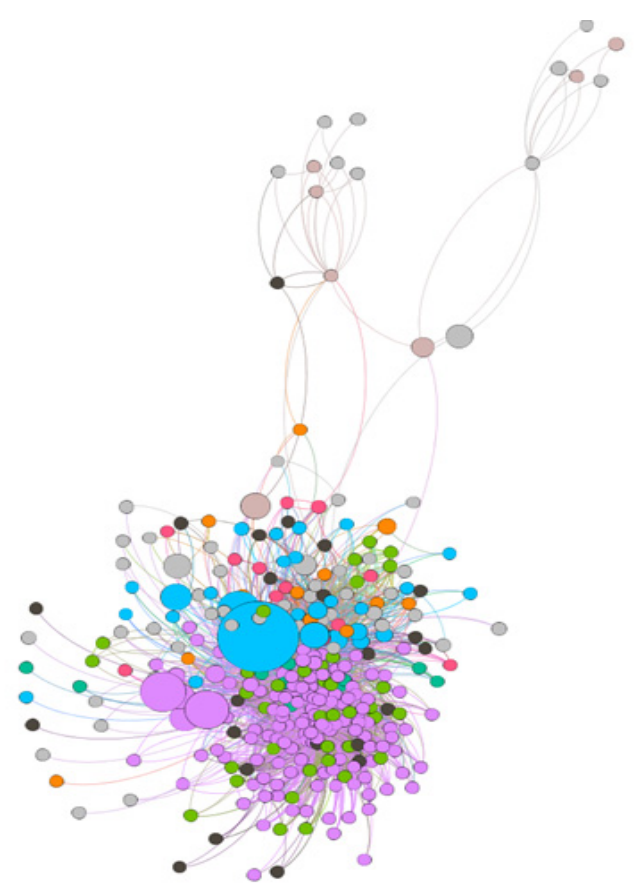

Figure 6. Dagbladet page like network 
as problematic for society. There is probably no simple answer to this question, but it is still an important issue to consider, and perhaps the most important contribution of this paper.

Either way you look at it, this personal framing brings new issues to the attention of thousands of new people through sharing in social media. If we assume that every user sharing an article has 100 unique friends, an article that is shared 42.000 times potentially reaches out to 4200000 people. That is $85 \%$ of the Norwegian population. The sum of this sharing certainly has implications both in the media and in parliament. Political parties spend many resources following the stories that trend in the media, looking for issues to comment on. Thus, it is likely that over time, the personal framing of opinions will have implications for which cases are put on the agenda of political parties.

The network analyses make these numbers more visible. Single issues framed as personal stories reach out to thousands of people who otherwise would not be exposed to this type of content. In an age where newspapers are still important for the public agenda, and at the same time concerned with reader numbers and shares in social media, the stories that we share, read and interacted with become important also for those in power. The page like networks show that the potential reach of these posts includes those who are interested in politics and society.

This study has several implications. For research, it adds to a growing pool of research on which types of content are being shared, by confirming that personal framing of opinions is effective in reaching a broader audience, which has implications for the topics being discussed in the public sphere. Recent events such as Trump being elected president and the Brexit vote could be seen as further confirmation of this. For practice, the research approach of combining framing and network analysis is a process that can be adopted by newspapers and journalists to track the impact and reach of the stories they publish. While Facebook's newly announced algorithm change might lead to fewer news stories showing up in newsfeeds, it remains to be seen if and how this will also affect stories being shared by individual users.

\section{Conclusion}

This paper has a few limitations that are worth noticing. First of all, existing studies of framing (see for example (Lecheler and de Vreese, 2012, Kang, 2013)) tend to focus on one topic or issue, and examine the framing surrounding this issue. As my approach was to examine what makes us share content, the analysis process was slightly different in that I had several topics with and a limited number of articles to analyse. Thus, the frames "deliberation" and personal account" should be seen as meta-frames, overarching frames that contain more specific framing about the topic. The data set for the frame analysis is somewhat limited, covering only 40 articles. Even so, the findings in this paper shows some interesting trends that are worth reporting. In addition, the paper identifies several possibilities for future research:

The framing analysis includes only a small subsection of opinion articles, and it would be useful to examine a larger sample, which also included an examination of the comment fields in newspapers, as well as comments on Facebook and Twitter conversations. The social network analysis could also have been extended to cover a larger variety of sources. However, the two examined newspapers are the most popular sources of opinion stories in Norway, and thus should be representative for the Norwegian context and likely transferable to similar countries. Finally, the role of technology in this process also needs a more thorough investigation, and a study of the affordances of social media in relation to dissemination and framing could be an interesting approach for this purpose.

\section{References}

[1] Barney, D. (2004). The network society, Cambridge, Polity Press.

[2] Bateson, G. (1972). Steps to an ecology of mind, Northwale, NJ, Jason Aronson.

[3] Benkler, Y. (2006). The wealth of networks: How social production transforms markets and freedom, Yale University Press.

[4] Bishop, R. (2013). Go out and play, but mean it: Using frame analysis to explore recent news media coverage of the rediscovery of unstructured play. The Social Science Journal, 50, 510-520.

[5] Blondel, V. D., Guillaume, J., Lambiotte, R., Lefebvre, E. (2008). Fast unfolding of communities in large networks. Journal of Statistical Mechanics: Theory and Experiment, 10.

[6] Brewer, M., Mccombs, M. (1996). Setting the Community Agenda. Journalism \& Mass Communication Quarterly, 73, 7-16.

$62 \quad$ Journal of E-Technology Volume 9 Number 2 May 2018


[7] Callon, M. (1998). An essay on framing and overflowing: Economic externalities revisited by sociology. In: CALLON, M. (ed.) The laws of the markets. Oxford: Blackwell Publishers / The Sociological Review.

[8] Castells, M. (2000). Materials for an exploratory theory of the network society1. The British Journal of Sociology, 51, 5-24.

[9] Chong, D., Druckman, J. N. (2007). Framing Theory. Annual Review of Political Science, 10, 103-126.

[10] Crawford, H., Hunter, A., Filipovic, D. (2015). All Your Friends Like This : how social networks took over the news, Sydney, Australia, Harper Collins.

[11] Dalton, R. J., Beck, P. A., Huckfeldt, R., Koetzle, W. (1998). A Test of Media-Centered Agenda Setting: Newspaper Content and Public Interests in a Presidential Election. Political Communication, 15, 463-481.

[12] Ebbers, W. E., Pieterson, W. J., Noordman, H. N. (2008). Electronic government: Rethinking channel management strategies. Government Information Quarterly, 25, 181-201.

[13] Goffman, E. (1974). Frame Analysis. an Essay on the Organization of Experience, Boston, Mass., Northeastern University Press.

[14] Graham, T. (2011). Beyond "Political" Communicative Spaces: Talking Politics on the Wife Swap Discussion Forum. Journal of Information Technology \& Politics, 9, 31-45.

[15] Grzywinska, I., Borden, J. (2012). The impact of social media on traditional media agenda setting theory. The case study of Occupy Wall Street Movement in USA. Agenda Setting: Old and New Problems in Old and New Media. Wroclaw.

[16] Guo, L. (2012). The Application of Social Network Analysis in Agenda Setting Research: A Methodological Exploration. Journal of Broadcasting \& Electronic Media, 56, 616-631.

[17] Hardisty, D. J., Johnson, E. J., Weber, E. U. (2010). A Dirty Word or a Dirty World?: Attribute Framing, Political Affiliation, and Query Theory. Psychological Science, 21, 86-92.

[18] Hermida, A., Fletcher, F., Korell, D., Logan, D. (2012). SHARE, LIKE, RECOMMEND. Journalism Studies, 13, 815-824.

[19] Kang, S. (2013). Coverage of autism spectrum disorder in the US television news: an analysis of framing. Disability \& Society, 28, 245-259.

[20] Katona, Z., Zubcsek, P. P., Sarvary, M. (2011). Network Effects and Personal Influences: The Diffusion of an Online Social Network. Journal of Marketing Research, 48, 425-443.

[21] Larsson, A. O. (2018). "I Shared the News Today, oh Boy”. Journalism Studies, 19, 43-61.

[22] Lecheler, S., De Vreese, C. H. (2012). News Framing and Public Opinion A Mediation Analysis of Framing Effects on Political Attitudes. Journalism \& mass communication quarterly, 89, 185-204.

[23] Lotan, G., Graeff, E., Ananny, M., Gaffney, D., Pearce, I. (2011). The Arab Spring| the revolutions were tweeted: Information flows during the 2011 Tunisian and Egyptian revolutions. International journal of communication, 5, 31.

[24] Macintosh, A., Mckay-hubbard, A., Shell, D. (2005). Using Weblogs to Support Local Democracy. In: BÖHLEN, M., Gamper, J., W., P. \& Wimmer, M. A. (eds.) E-Government: Towards Electronic Democracy. Springer.

[25] Mazur, A., Doran, C., Doran, P. R. (2010). The use of social network analysis software to analyze communication patterns and interaction in online collaborative environments. International Conference on Education, Training and Informatics, ICETI. Orlando, FL.

[26] Mcadam, D., Mccarthy, J. D., Zald, M. N. (1996). Introduction: Opportunities, mobilizing structures, and framing processes - toward a synthetic, comparative perspective on social movements. In: Mcadam, D., Mccarthy, J. D. \& Zald, M. N. (eds.) Comparative Perspec-tives on Social Movements. Cambridge: Cambridge University Press.

[27] Mccombs, M., Ghanem, S. I. (2001). The convergence of agenda setting and framing. Framing public life: Perspectives on media and our understanding of the social world. Taylor \& Francis e-library.

[28] Meraz, S. (2009). Is There an Elite Hold? Traditional Media to Social Media Agenda Setting Influence in Blog Networks. Journal of Computer-Mediated Communication, 14, 682-707.

[29] Nelson, T. E., Clawson, R. A., Oxley, Z. M. (1997). Media Framing of a Civil Liberties Conflict and Its Effect on Tolerance. American Political Science Review, 91, 567-583.

Journal of E-Technology Volume 9 Number 2 May 2018 
[30] Otte, E., Rousseau, R. (2002). Social network analysis: a powerful strategy, also for the information sciences. Journal of Information Science, 28, 441-453.

[31] PArk, H. W., Jankowski, N. W. (2008). A hyperlink network analysis of citizen blogs in South Korean politics. Javnost-The Public, 15.

[32] Rayner, S. (2003). Democracy in the age of assessment: Reflections on the roles of expertise and democracy in public-sector decision making. Science and Public Policy, 30, 163-170.

[33] Reese, S. D. (2010). Finding frames in a web of culture. 2010. Doing News Framing Analysis: Empirical and Theoretical Perspectives, 17-42.

[34] Sandberg, S. (2003). The success of ATTAC in Norway: an approach synthesising discourse analysis and framing theory.

[35] Silberberg, R. (2008). Journalistic Framing of the Food and Drug Administration: How Do Our Nation's Most Respected Newspapers Report About the FDA?

[36] Skogerbø, E., Moe, H. (2015). Twitter på tvers - koblinger mellom journalister og politikere. Norsk medietidsskrift, 22, 1-21

[37] Smith, M. A., Shneiderman, B., Milic-frayling, N., Rodrigues, E. M., Barash, V., Dunne, C., Capone, T., Perer, A., Gleave, E. (2009). Analyzing (social media) networks with NodeXL. Proceedings of the fourth international conference on Communities and technologies. University Park, PA, USA: ACM.

[39] Svendsen, G. T., Svendsen, G. L. H. (2006). Social Kapital - en introduktion, København, Hans Reitzels Forlag.

[40] Tewksbury, D., Scheufele, D. A. (2009). News framing theory and research. Media effects: Advances in theory and research. 3rd ed. Hillsdale, NJ: Erlbaum.

[41] Wadbring, I., Ödmark, S. (2016). Going Viral : News Sharing and Shared News in Social Media. OBS - Observatorio, 10, $132-$ 149 .

[42] Weaver, D. H. (2007). Thoughts on Agenda Setting, Framing, and Priming. Journal of Communication, 57, 142-147.

[43] Weeks, B. E., Holbert, R. L. (2013). Predicting dissemination of news content in social media: A focus on reception, friending, and partisanship. Journalism \& Mass Communication Quarterly, 90, 212-232.

[44] Weick, K. E. (1995). Sensemaking in organizations, Thousand Oaks, CA, Sage Publications Ltd.

[45] Weick, K. E., Sutcliffe, K. M., D., O. (2005). Organizing and the process of sensemaking. Organization Science, 16, 409-421.

[46] Yarnell, S. M. (1985). Frame Analysis. Psychology and Marketing, 2, 31-40. 